Article

\title{
Advanced Open-Celled Structures from Low-Temperature Sintering of a Crystallization-Resistant Bioactive Glass
}

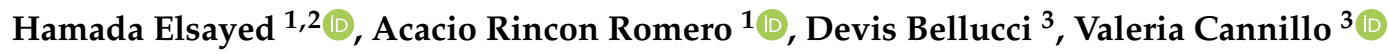 \\ and Enrico Bernardo 1,*(D) \\ 1 Department of Industrial Engineering, Università degli Studi di Padova, 35122 Padova, Italy; \\ hamada.elsayed@unipd.it (H.E.); acacio.rinconromero@unipd.it (A.R.R.) \\ 2 Ceramics Department, National Research Centre, Cairo 12622, Egypt \\ 3 Dipartimento di Ingegneria "E. Ferrari", Università degli Studi di Modena e Reggio Emilia, \\ Via Vignolese 905, 41125 Modena, Italy; devis.bellucci@unimore.it (D.B.); valeria@unimore.it (V.C.) \\ * Correspondence: enrico.bernardo@unipd.it; Tel.: +39-049-827-5510; Fax: +39-049-827-5505
}

Received: 8 October 2019; Accepted: 5 November 2019; Published: 6 November 2019

\begin{abstract}
Most materials for bone tissue engineering are in form of highly porous open-celled components (porosity $>70 \%$ ) developed by means of an adequate coupling of formulations and manufacturing technologies. This paper is dedicated to porous components from BGMS10 bioactive glass, originally designed to undergo viscous flow sintering without crystallization, which is generally known to degrade the bioactivity of $45 S 5$ bioglass. The adopted manufacturing technologies were specifically conceived to avoid any contamination and give excellent control on the microstructures by simple operations. More precisely, 'green' components were obtained by digital light processing and direct foaming of glass powders suspended in a photosensitive organic binder or in an aqueous solution, activated with an organic base, respectively. Owing to characteristic quite large sintering window of BGMS10 glass, sintering at $750{ }^{\circ} \mathrm{C}$ caused the consolidation of the structures generated at room temperature, without any evidence of viscous collapse.
\end{abstract}

Keywords: bioglass; crystallization-resistant bioactive glasses; sintering; foams; additive manufacturing; scaffolds

\section{Introduction}

Despite being useful in particulate form (e.g., embedded in polymer matrices) [1,2], bioactive glasses are mostly used in the form of scaffolds, with stochastic and non-stochastic open porosity (foams and reticulated scaffolds, respectively) [3]. The manufacturing of these structures is intrinsically conditioned by the control of viscous flow sintering of fine glass particles. More precisely, pressureless glass sintering occurs $50-100{ }^{\circ} \mathrm{C}$ above the dilatometric softening temperature [4] (corresponding to a viscosity of $10^{11.5} \mathrm{~Pa} \cdot \mathrm{s}$ ), in turn placed slightly above the transition temperature $\mathrm{T}_{\mathrm{g}}$ (but well below "Littleton" softening point, indicating gross viscous flow, for a viscosity of approximately $10^{6.6} \mathrm{~Pa} \cdot \mathrm{s}$ ) [5] and often overlapping with the crystallization temperature [6]. The overlapping is also stimulated by the use of fine particles possessing a wide specific surface: in case of glasses sensitive to surface-induced crystallization, the crystallization temperature is so downshifted, with decreasing powder size, that the devitrification practically nullify the viscous flow [6] (rigid inclusions provide a significant increase of viscosity in softened glass [7]).

Sintering with concurrent devitrification ('sinter-crystallization'), for $45 \mathrm{~S} 5$ bioglass ${ }^{\circledR}$, has a fundamental drawback in limiting the bioactivity [8]. This negative aspect may be overcome by revising the chemical formulation, i.e., producing new bioactive glasses, with two distinct aims: 
(i) adjusting the amount and nature of crystal phases developed upon firing, in order to achieve the bioactivity of $45 \mathrm{~S} 5$ with a semi-crystalline material (e.g., Biosilicate ${ }^{\circledR}$ glass-ceramic, developed by Zanotto and coworkers [9,10]); (ii) realizing a quite large temperature gap ('processing window') between softening and crystallization, in 'crystallization-resistant bioactive glasses' (including the well-known 13-93 bioactive glass) [11-13]. BGMS10 glass, the object of the present studies, belongs to the latter type [14,15].

Compared to $45 \mathrm{~S} 5$ bioglass, the bioactive glass BGMS10 contains a lower content of alkali oxides, but it features the presence of magnesium and strontium oxides, thus bringing extra ions $\left(\mathrm{Mg}^{2+}\right.$ and $\left.\mathrm{Sr}^{2+}\right)$ with a well established positive impact on biological properties [16]. Previous tests have shown that BGMS10 behaves very similarly to $45 S 5$ in terms of in vitro bioactivity and in vivo biocompatibility $[14,15,17]$.

Once a glass with low crystallization tendency and comfortable processing window is selected, attention must be paid to the manufacturing technique adopted for the obtainment of highly porous, open-celled components, matching the microstructural requirements of materials for bone tissue engineering (e.g., pores well-defined interconnections, with a diameter exceeding $100 \mu \mathrm{m}$, to allow effective tissue ingrowth and vascularization [18]).

A key condition is that the applied technology should not interfere with the microstructural evolution of glass powders upon thermal treatments; in other words, additives and/or particular processing conditions (e.g., use of very fine powders) should not determine changes in the crystallization tendency or cause a viscous collapse of the structures defined in the 'green' state.

The use of sacrificial organic binders is fundamental; among them, photocurable resins are undoubtedly precious in enabling the manufacturing of scaffolds with non-stochastic porosity by means of high-resolution stereolithography 3D printing [19]. When considering suspensions of fine glass particles in photocurable resin (i.e., a bi-phasic mixture), instead of photocurable liquid (a monophasic system), the resolution is obviously conditioned by the particle size and by light scattering at the liquid-particle interfaces [20-22]; anyway, highly uniform samples, even with complex geometries, were successfully obtained starting from glass undergoing sinter-crystallization [23,24]. The sudden increase of viscosity, caused by crystal precipitation, prevented any collapse of cellular structure upon firing. The shape retention had been observed also in stereolithography experiences with bioglass $45 S 5$ [25,26]; however, in this specific case, samples exhibited quite poor mechanical properties and were partially crystallized (with a negative impact on bioactivity, as discussed above). The present investigation aims at demonstrating the suitability of stereolithography for the manufacturing of reticulated scaffolds with good shape retention upon firing, despite the absence of crystallization, owing to the use of BGMS10 bioactive glass.

The use of fugitive organic binders is useful also for the obtainment of open-celled foams by gel-casting, i.e., by intensive mechanical stirring and incorporation of air bubbles (with the support of surfactants) in liquids undergoing progressive gelation. Widely applied to bioactive glasses from sol-gel approach $[27,28]$ (operating on solutions of metallorganic compounds), the process has been successfully applied to suspensions of glass powders, subjected to gelation according to the addition of a quite complex mixture of organic agents, such as monomers, cross-linkers, and catalysts [29,30]. Air bubbles are stabilized by the characteristic gelation-induced pseudoplasticity, i.e., by the sudden increase of viscosity upon reduction of strain rate (low viscosity upon intensive stirring, high viscosity when stirring stops). Porous samples are formed already in the 'green' state (dried suspension) before final consolidation by viscous flow sintering.

The present investigation, besides discussing the application of stereolithography 3D printing to BGMS10, aims at disclosing the potential of a simplified approach to gel-casting of bioactive glass foams, deriving from recent experiences on the alkali activation of glass aqueous suspensions [31]. According to alkaline attack, gelation is achieved by formation of an inorganic binding phase (instead of an organic, polymeric phase), consisting of hydrated silicate and/or carbonate compounds, involving ions extracted from the glass $\left(\mathrm{Ca}^{2+}\right)$ and/or from the alkaline activator $\left(\mathrm{Na}^{+}, \mathrm{K}^{+}\right.$, from $\mathrm{NaOH}$ and $\mathrm{KOH}$, 
respectively). Although highly effective (and flexible, i.e., open to a vast range of glasses [32-34]), the process has a substantial drawback in the contamination of the adopted glass operated by oxides in the binding phase, decomposed upon firing; in particular, a surplus of alkali oxides may modify both biological behavior and crystallization (it was observed that alkali activation may widen and shift the crystallization exothermic peak at lower temperature [32]). With the present paper, we will show the feasibility of a 'hybrid' activation, which recovers the concept of gelation as an effect of glass inclusion in a basic environment, but avoids contamination, owing to the use of an ammonium salt.

\section{Materials and Methods}

The chemical composition of BGMS10 glass is reported in Table 1. The glass batch was prepared from analytical grade powder reagents (from Carlo Erba Reagenti, Milano, Italy) and melted at $1450{ }^{\circ} \mathrm{C}$ in a Pt crucible, in air. The molten material was suddenly cooled by pouring into deionized water. The drastic quenching provided a number of fragments, subsequently left to dry at $110^{\circ} \mathrm{C}$ for $2 \mathrm{~h}$. The frit was later reduced into fine powders, with a size below $38 \mu \mathrm{m}$, by dry ball milling and manual sieving.

Table 1. Chemical formulation of BGMS10 bioactive glass.

\begin{tabular}{ccc}
\hline \multirow{2}{*}{ Oxide } & \multicolumn{2}{c}{ BGMS10 Glass } \\
\cline { 2 - 3 } & mol\% & wt. $\%$ \\
\hline $\mathrm{SiO}_{2}$ & 47.2 & 44.6 \\
\hline $\mathrm{CaO}$ & 25.6 & 22.6 \\
\hline $\mathrm{MgO}$ & 10 & 6.3 \\
\hline $\mathrm{SrO}$ & 10 & 16.3 \\
\hline $\mathrm{Na}_{2} \mathrm{O}$ & 2.3 & 2.2 \\
\hline $\mathrm{K}_{2} \mathrm{O}$ & 2.3 & 3.4 \\
\hline $\mathrm{P}_{2} \mathrm{O}_{5}$ & 2.6 & 4.5 \\
\hline
\end{tabular}

Samples with non-stochastic porosity were manufactured by using DLP (digital light processing), in analogy with previous experiences $[23,24]$. Fine glass powders were suspended in a commercially available photocurable acrylic polymer (Tripropylene glycol diacrylate, Robot Factory S.R.L., Mirano, Italy), already comprising a suitable photo-initiator and photo-absorber, for a solid load of $60 \mathrm{wt}$. \%. The suspension was printed using a printer (3DLPrinter-HD 2.0, Robotfactory S.R.L., Mirano, Italy) operating in the visible light range (between 400 and $500 \mathrm{~nm}$ ). After cleaning in an ultrasonic bath with isopropanol for $3 \mathrm{~min}$, the samples were subjected to a secondary curing step, in a UV curing chamber (operating wavelength $365 \mathrm{~nm}$, Robot Factory S.R.L., Mirano, Italy), for $15 \mathrm{~min}$. Finally, the samples underwent a preliminary heat treatment in the air $\left(1{ }^{\circ} \mathrm{C} / \mathrm{min}\right.$ heating rate) at $550{ }^{\circ} \mathrm{C}$ for $5 \mathrm{~h}$, aimed at the burn-out of the photo-cured binder.

'Green' glass foam samples were prepared according to frothing of an aqueous suspension of fine glass powders, for a solid loading of $65 \mathrm{wt}$. \%, activated by addition of tetramethyl-ammonium hydroxide (TMAH, $\left(\mathrm{CH}_{3}\right)_{4} \mathrm{NOH}$, reagent grade, Sigma-Aldrich, Gillingham, UK) in a concentration of $1 \mathrm{~mol} / \mathrm{L}$. Glass slurries were firstly kept under low-speed mechanical stirring ( $500 \mathrm{rpm}$ ) for $3 \mathrm{~h}$ to induce partial dissolution and gelation. Secondly, the slurries were foamed by vigorous mechanical mixing (2000 rpm) for $5 \mathrm{~min}$ after the addition of $4 \mathrm{wt}$. \% Triton X-100 (polyoxyethylene octyl phenyl ether, Sigma-Aldrich, Gillingham, UK) and subsequently cast in polystyrene moulds (50 mm diameter). Finally, the foams were dried at $40^{\circ} \mathrm{C}$ for $24 \mathrm{~h}$, demoulded and subjected to a preliminary heat treatment in air at $350{ }^{\circ} \mathrm{C}\left(5^{\circ} \mathrm{C} / \mathrm{min}\right.$ heating rate) for $1 \mathrm{~h}$ for the burn-out of organics. 
Both reticulated and foamed scaffolds, after relative preliminary heat treatments, underwent a sintering treatment in air at $750{ }^{\circ} \mathrm{C}$ (with heating rate of $1{ }^{\circ} \mathrm{C} / \mathrm{min}$ up to $500{ }^{\circ} \mathrm{C}$, then with $5^{\circ} \mathrm{C} / \mathrm{min}$ up to $750^{\circ} \mathrm{C}$ ) for $1 \mathrm{~h}$, followed by natural cooling.

The evolution of samples was investigated by means of Fourier transform IR spectroscopy (FTIR, FTIR model 2000, Perkin Elmer, Waltham, MA, USA), X-ray diffraction on powders (XRD; Bruker AXS D8 Advance, Bruker, Germany) and thermal analysis (thermogravimetry and differential scanning calorimetry, TG/DSC; Mettler Toledo TGA/DSC $3^{+}$, STARe System, Columbus, OH, USA).

The bulk density was computed from the weight-to-volume ratios on regular blocks (cut from bigger foamed samples or directly available from DLP), after careful determinations of weights and dimensions by means of an analytical balance and of a digital caliper, respectively. The apparent and true densities of the various samples were measured by He gas pycnometry (Micromeritics AccuPyc 1330, Norcross, GA, USA), applied on samples in bulk and powder forms. Morphological and microstructural characterizations were performed by optical stereomicroscopy (AxioCam ERc $5 \mathrm{~s}$ Microscope Camera, Carl Zeiss Microscopy, Thornwood, New York, NY, USA) and scanning electron microscopy (FEI Quanta 200 ESEM, Eindhoven, The Netherlands).

The compressive strength of the porous glass scaffolds was measured at room temperature by means of an Instron 1121 UTM (Instron, Danvers, MA, USA) operating with a cross-head speed of $0.5 \mathrm{~mm} / \mathrm{min}$. Each data point represents the average value of at least 10 individual tests.

\section{Results}

A first series of investigations concerned the application of stereolithography to BGMS10, starting from a diamond cell design recently tested for wollastonite-diopside glass-ceramics [24], as illustrated by Figure 1. The particular design, maximizing the bending of thin struts, was chosen specifically to verify the resistance of BGMS10 to viscous collapse upon firing.

The limited morphological changes from samples in the printed state, shown in Figure 1a,b, to samples after firing, illustrated by Figure 1c, clearly show that by operating at the lower limit for pressureless sintering (with $\mathrm{T}_{\mathrm{g}} \sim 670{ }^{\circ} \mathrm{C}[14]$, the firing temperature $-750{ }^{\circ} \mathrm{C}$, i.e. $\mathrm{T}_{\mathrm{g}}+80^{\circ} \mathrm{C}$, was in the range of dilatometric softening temperature), a good shape retention could be achieved despite the absence of crystallization (in previous experiments with wollastonite-diopside glass-ceramics [24] the shape was maintained as an effect of viscosity enhancement operated by intensive crystal precipitation). BGMS10 was evidently a 'long' glass, i.e., not exhibiting an abrupt decrease of viscosity with increasing temperature above $\mathrm{T}_{\mathrm{g}}$. The fully amorphous state is demonstrated in Figure 2, and it is consistent with the DSC curve of Figure 3, displaying the crystallization temperature far above the adopted sintering temperature. 

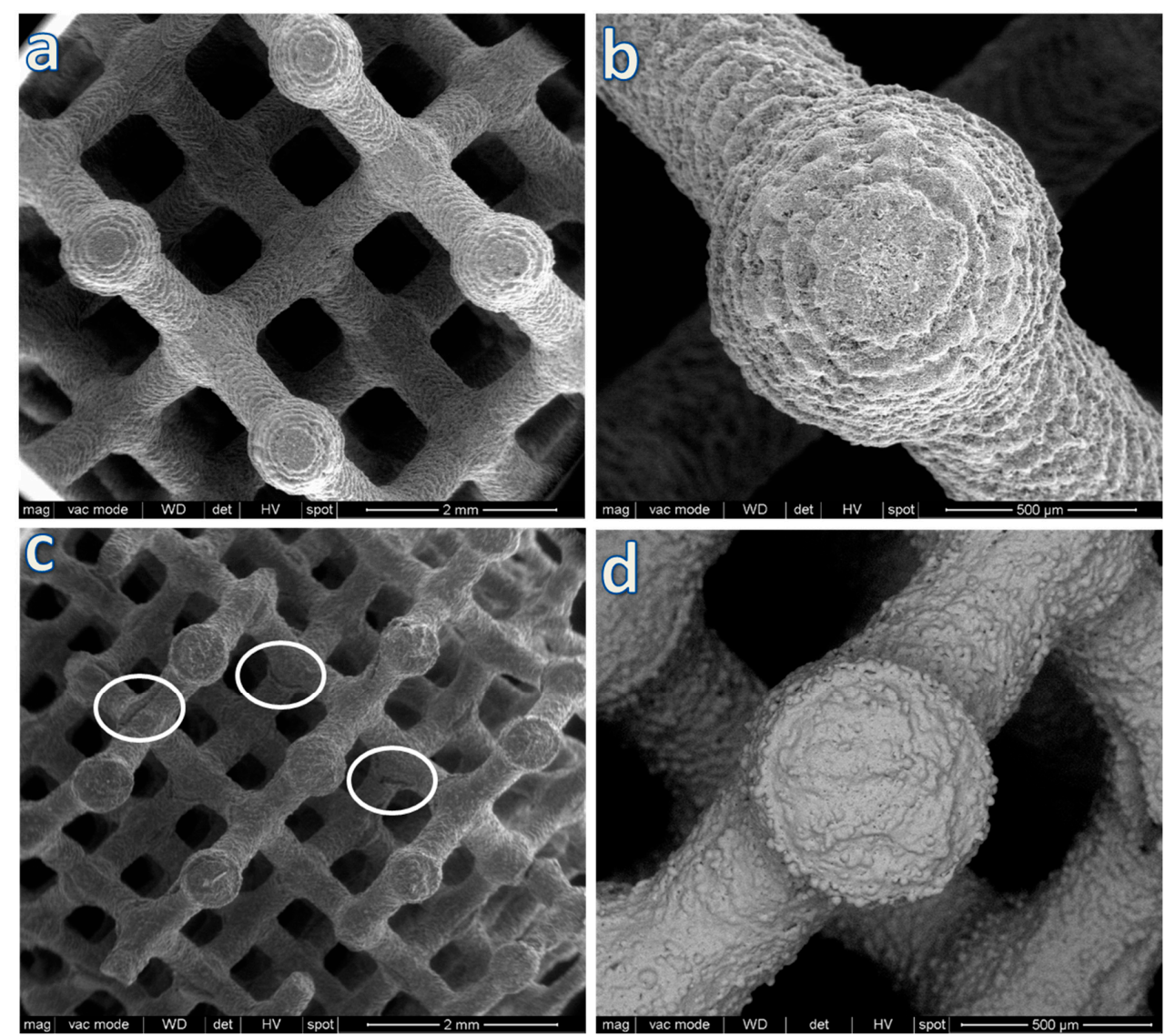

Figure 1. Microstructural details of a scaffold with diamond cell design after printing; $(\mathbf{a}, \mathbf{b})$ before firing and (c,d) after firing at $750{ }^{\circ} \mathrm{C}$.

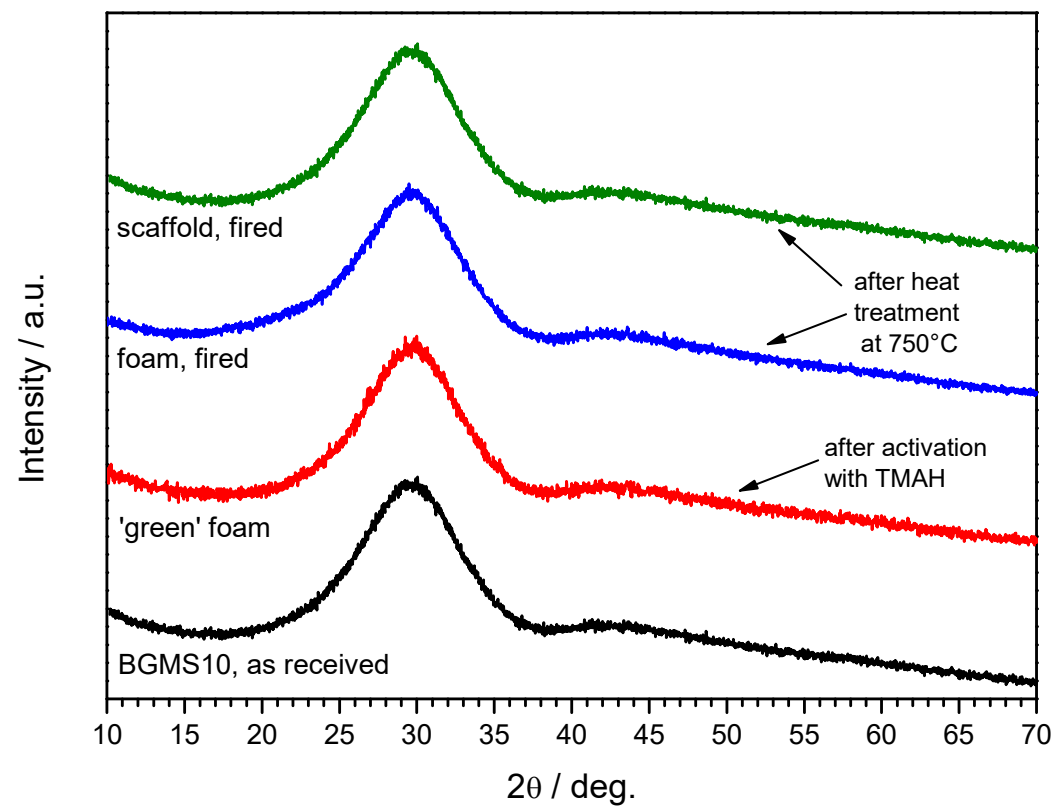

Figure 2. Mineralogical analysis of BGMS10 glass as received, activated with tetramethyl-ammonium hydroxide (TMAH) and after firing at $750{ }^{\circ} \mathrm{C}$ (foam and scaffold). 


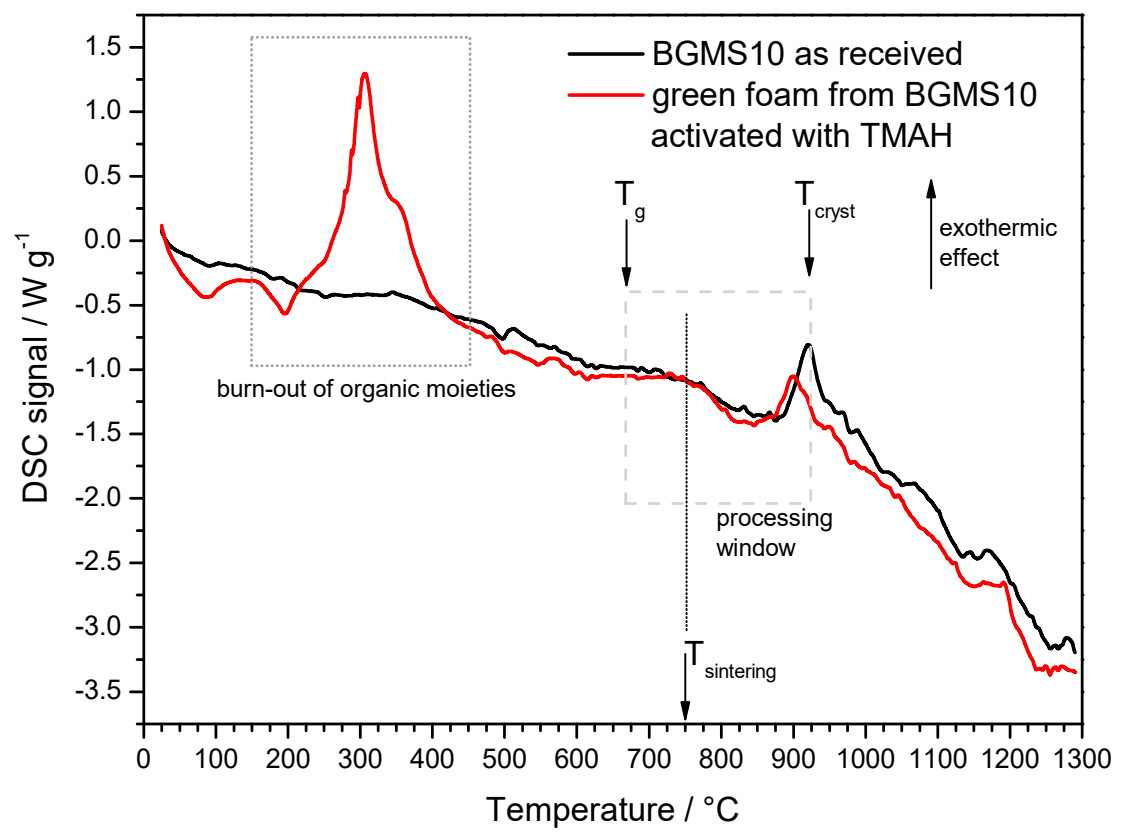

Figure 3. DSC plot of BGMS10 glass in the as received conditions and in the form of 'green' foam.

All printed samples were opaque white as an effect of the presence of tiny micropores (see the small black dots in Figure 1d) and some roughness (Figure 1d still displays the former glass granules). The circles in Figure 1c actually evidence some defects likely originating from not optimized debinding, i.e., gas release, from the burn-out of the acrylic resin, overlapping with the sintering phase and leading to some cracks. Since BGMS10 did not undergo crystallization, the viscous flow provided some healing of the same cracks, saving the integrity of samples.

The saving of structural integrity can be understood from the results of mechanical testing. The diamond cell structure had been selected also as an example of 'bending dominated' design [24]. According to Gibson and Ashby [35], the crushing of brittle solids with such morphology, causing the systematic buckling of the struts, is described by a simple equation:

$$
\sigma_{\mathrm{c}}=0.2 \cdot \sigma_{\text {bend }} \cdot\left(\varrho_{\text {rel }}\right)^{1.5}
$$

where $\sigma_{\mathrm{c}}$ represents the compressive strength, $\sigma_{\text {bend }}$ is the bending strength of the solid phase, and $\varrho_{\text {rel }}$ is the relative density (ratio between geometric and true densities). The observed crushing strength $\left(\sigma_{\mathrm{C}}=0.49 \pm 0.03 \mathrm{MPa}\right.$, see Table 2$)$ cannot be considered as low; in fact, according to the low relative density (slightly exceeding 0.1 , with a total porosity of nearly 90 vol. \%), the bending strength of the solid phase, predicted by reversing Equation $(1)\left(\sigma_{\text {bend }}=5 \cdot \sigma_{\mathrm{c}} \cdot\left(\rho_{\text {rel }}\right)^{-1.5}\right)$, is about $71 \mathrm{MPa}$, in excellent agreement with the bending strength values of silicate glasses [36] despite the presence of the above mentioned debinding defects.

Table 2. Summary of density and compressive strength data for all developed cellular glasses.

\begin{tabular}{|c|c|c|c|c|c|c|c|}
\hline \multicolumn{2}{|c|}{ Cellular Structure } & \multirow{2}{*}{$\begin{array}{c}\begin{array}{c}\text { Bulk } \\
\text { Density } \\
\left(\mathrm{g} / \mathrm{cm}^{3}\right)\end{array} \\
0.31 \pm 0.05\end{array}$} & \multirow{2}{*}{$\begin{array}{c}\begin{array}{c}\text { Apparent } \\
\text { Density } \\
\left(\mathrm{g} / \mathrm{cm}^{3}\right)\end{array} \\
2.93 \pm 0.02\end{array}$} & \multirow{2}{*}{$\begin{array}{c}\begin{array}{c}\text { True } \\
\text { Density } \\
\text { (g/cm }\end{array} \\
3.00 \pm 0.02\end{array}$} & \multirow{2}{*}{$\begin{array}{c}\begin{array}{c}\text { Total } \\
\text { Porosity } \\
\text { (\%) }\end{array} \\
90\end{array}$} & \multirow{2}{*}{$\begin{array}{c}\begin{array}{c}\text { Open } \\
\text { Porosity } \\
\text { (\%) }\end{array} \\
89.4\end{array}$} & \multirow{2}{*}{$\begin{array}{c}\begin{array}{c}\text { Compressive } \\
\text { Strength (MPa) }\end{array} \\
0.49 \pm 0.03\end{array}$} \\
\hline & Diamond & & & & & & \\
\hline Reticulated & Cubic, $4 \times 4$ & $1.12 \pm 0.04$ & $2.93 \pm 0.02$ & $3.02 \pm 0.02$ & 63 & 61.8 & $7.67 \pm 0.61$ \\
\hline & Cubic, $6 \times 6$ & $1.39 \pm 0.03$ & $2.93 \pm 0.02$ & $2.96 \pm 0.02$ & 53 & 50.6 & $15.53 \pm 1.30$ \\
\hline \multicolumn{2}{|c|}{ Foam } & $0.57 \pm 0.03$ & $2.94 \pm 0.02$ & $3.17 \pm 0.02$ & 82 & 80.5 & $1.92 \pm 0.10$ \\
\hline
\end{tabular}

Much stronger scaffolds (with a compressive strength well exceeding $7 \mathrm{MPa}$, see Table 2) were developed by using a second design, as illustrated by Figure 4 . Cubic samples were derived by the 
overlapping of smaller cubic cells in a variable number ( 4 or 6 cells per side, as shown by Figures 4 a and $4 \mathrm{~b}$, respectively). In this case, the application of the model from Gibson and Ashby would not be appropriate, considering the much thicker struts and the lower porosity (from 50 to 62 vol. \%). The debinding defects favored by the increased strut thickness, with the new design, were again healed by the viscous flow of BGMS10, as shown by Figure 4c.
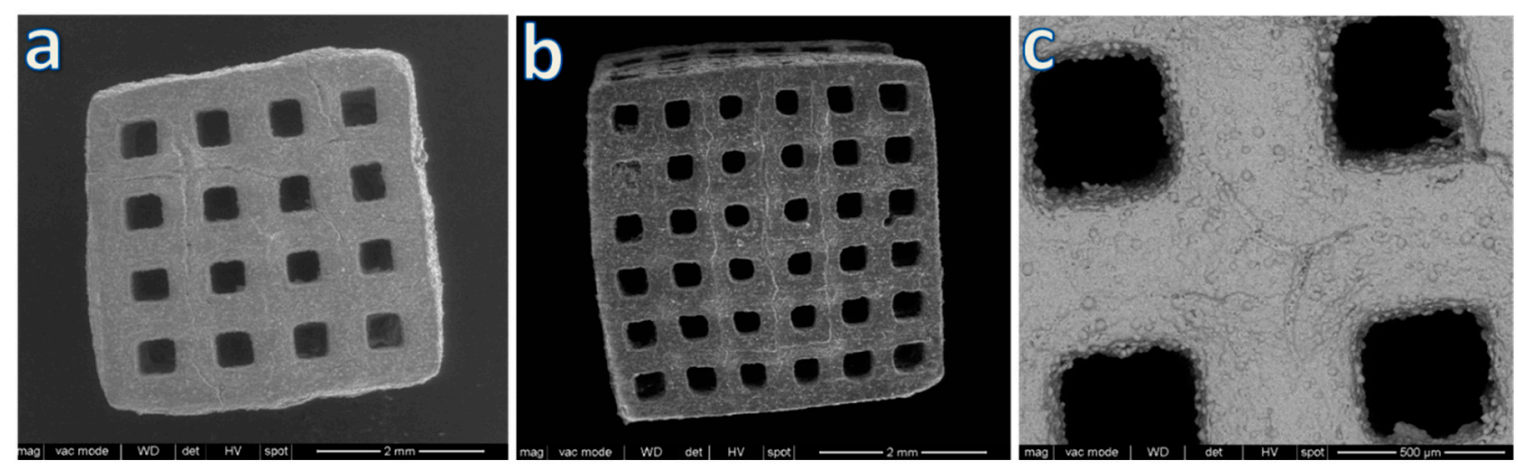

Figure 4. Microstructural details of samples from cubic cell design: (a) 4 cells per side; (b) 6 cells per side; (c) crack healing by viscous flow.

The adopted designs, 'thin-walled' (diamond cell) and 'thick-walled' (cubic cell), may be seen as two 'extreme' solutions in DLP of BGMS10, useful to appreciate the successful combination of densification with retention of both shape and amorphous state. Additional efforts will be undoubtedly dedicated, in the near future, in the manufacturing of scaffolds with different strut length/thickness ratio, different overall geometry and adjusted debinding phase.

The second series of investigations concerned the effectiveness of activation of aqueous slurries by means of the adopted organic base, compared to alkali activation. Suspensions of glass powders in $\mathrm{NaOH}$ or $\mathrm{KOH}$ solution typically undergo gelation by formation of hydrated silicate and carbonate compounds [31-34] that could be detected by means of infrared spectroscopy and X-ray diffraction analysis.

Figure 5a shows a 'green' foam after the drying step. The new activation was successful in causing the gelation of the glass slurry and stabilization of air bubbles, incorporated by intensive mechanical stirring. According to Figure 5b, particles were effectively 'glued' together, in analogy with what found with $\mathrm{NaOH}$ or $\mathrm{KOH}$ solutions. However, the nature of the surface compounds did not correspond with that previously achieved. 


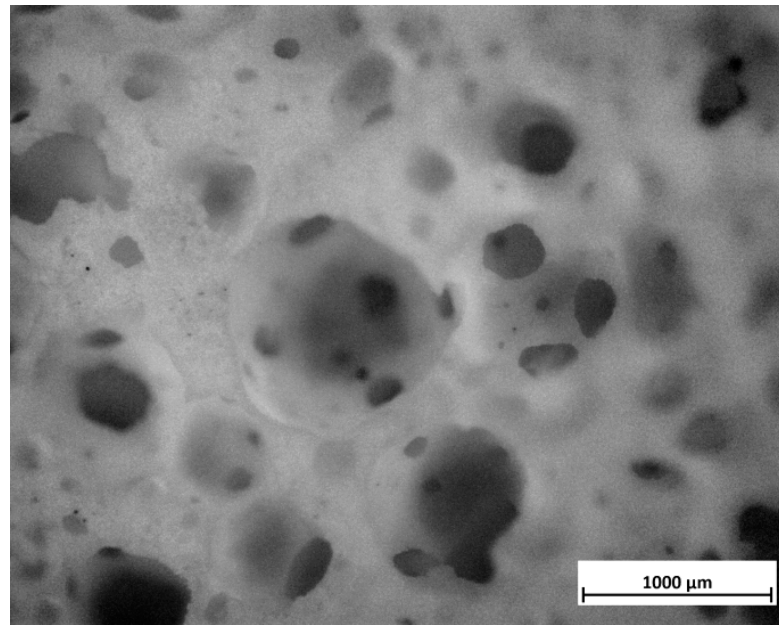

(a)

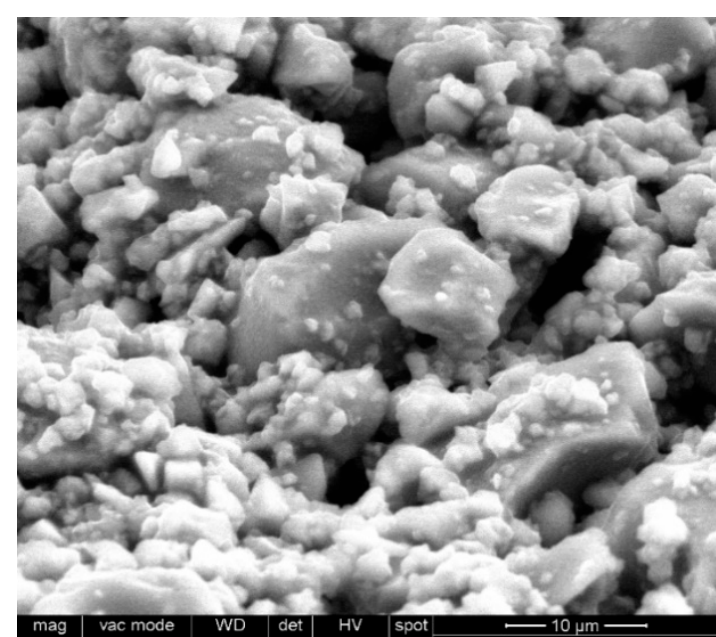

(b)

Figure 5. Green foam after activation of BGMS10 with TMAH: cellular structure (a, optical stereomicroscopy image); detail of cell wall (b, SEM image).

The FTIR spectra in Figure 6 shows many bands in samples after activation ('green' foams) but absent either in the starting glass or in fired foams. Like in the case of $\mathrm{NaOH}$ and $\mathrm{KOH}$ activation [32], the bands at 3000-3700 and $1650 \mathrm{~cm}^{-1}$ are attributable to hydration of BGMS10 glass (O-H stretching and bending), but there is no clear carbonation (the C-O bond is usually detected by a well-defined peak centered at about $1450 \mathrm{~cm}^{-1}$ ) [31,32]. The surfactant is clearly distinguishable from the bands labeled with 'S' (particularly that $2900 \mathrm{~cm}^{-1}$ ). Contribution to the IR absorption came also from TMAH (see symbols in Figure 5, denoting major absorption bands [37]). The band at $1250 \mathrm{~cm}^{-1}$ may be attributed again to the activator, being reported for the C-N stretching vibration [38].

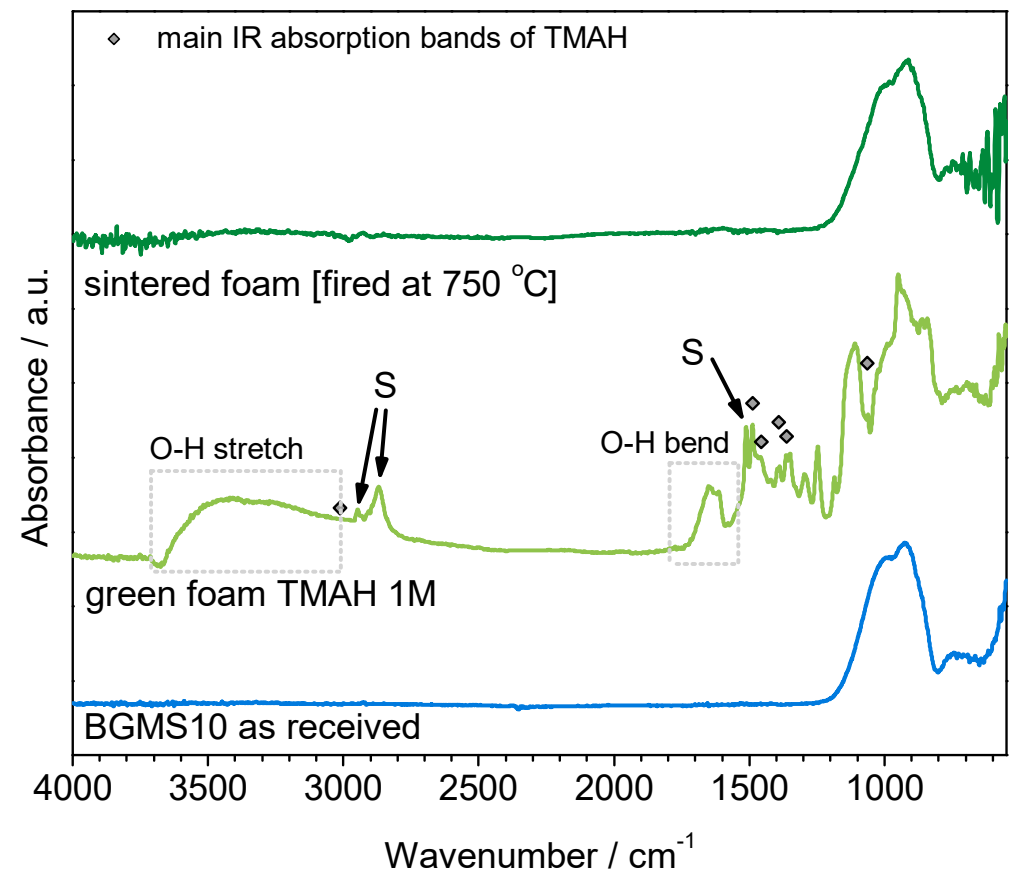

Figure 6. FTIR spectra of BGMS10 before and after activation and after firing.

The numerous bands below $1300 \mathrm{~cm}^{-1}$ are quite interesting in revealing a more intense silica dissolution than in the cases of attack by $\mathrm{NaOH}$ or $\mathrm{KOH}$ (at low molarity). The band at $1120 \mathrm{~cm}^{-1}$ can be attributed to the stretching vibration of $\mathrm{Si}-\mathrm{O}$ bonds in free $\mathrm{SiO}_{4}$ tetrahedra, as found in colloidal silica [39]; the bands centered at $900 \mathrm{~cm}^{-1}$ finds analogies with silica hydrated gels [40-42]. 
Finally, the sharp band standing at $970 \mathrm{~cm}^{-1}$ identifies the presence of Si-OH groups of the hydrated gel $[43,44]$.

Unlike in previous cases, the activation with TMAH could not be recognized by formation of crystalline phases or by shifts in the peak position of the amorphous halo (typical of the X-ray diffraction of glasses), as shown by Figure 2. Furthermore, the firing at $750{ }^{\circ} \mathrm{C}$ again did not cause any crystallization.

The thermogravimetric plot, shown in Figure 7a, revealed a continuous weight loss of the dried sample up to the sintering temperature, up to $15 \mathrm{wt}$. \%, i.e., far exceeding the contribution of the surfactant (4 wt. \%). Interestingly, the overall loss matched almost perfectly that of a bioactive glass (undergoing sinter-crystallization upon firing) previously activated with $\mathrm{NaOH}$-containing solution (1 M) [32], reported in Figure $7 \mathrm{~b}$ (also displaying the weight loss of Triton X-100). A substantial difference is represented by the fact that with TMAH-induced activation most of the weight loss occurred below $500{ }^{\circ} \mathrm{C}$, while with $\mathrm{NaOH}$ more than one-fifth of the total loss was achieved above this threshold. 'High-temperature losses' with $\mathrm{NaOH}$ activation were ascribed to the decomposition of calcium silicate hydrated (C-S-H) compounds, known to release water vapor above $500{ }^{\circ} \mathrm{C}$ [45]. The losses for TMAH-activated BGMS10 are reasonably due to the evolution of physically adsorbed water (released below $200^{\circ} \mathrm{C}$ ) as well as condensation of silanol groups formed at the surface of glass particles, upon basic attack. We cannot exclude a minor contribution of organic moieties evolving from TMAH.
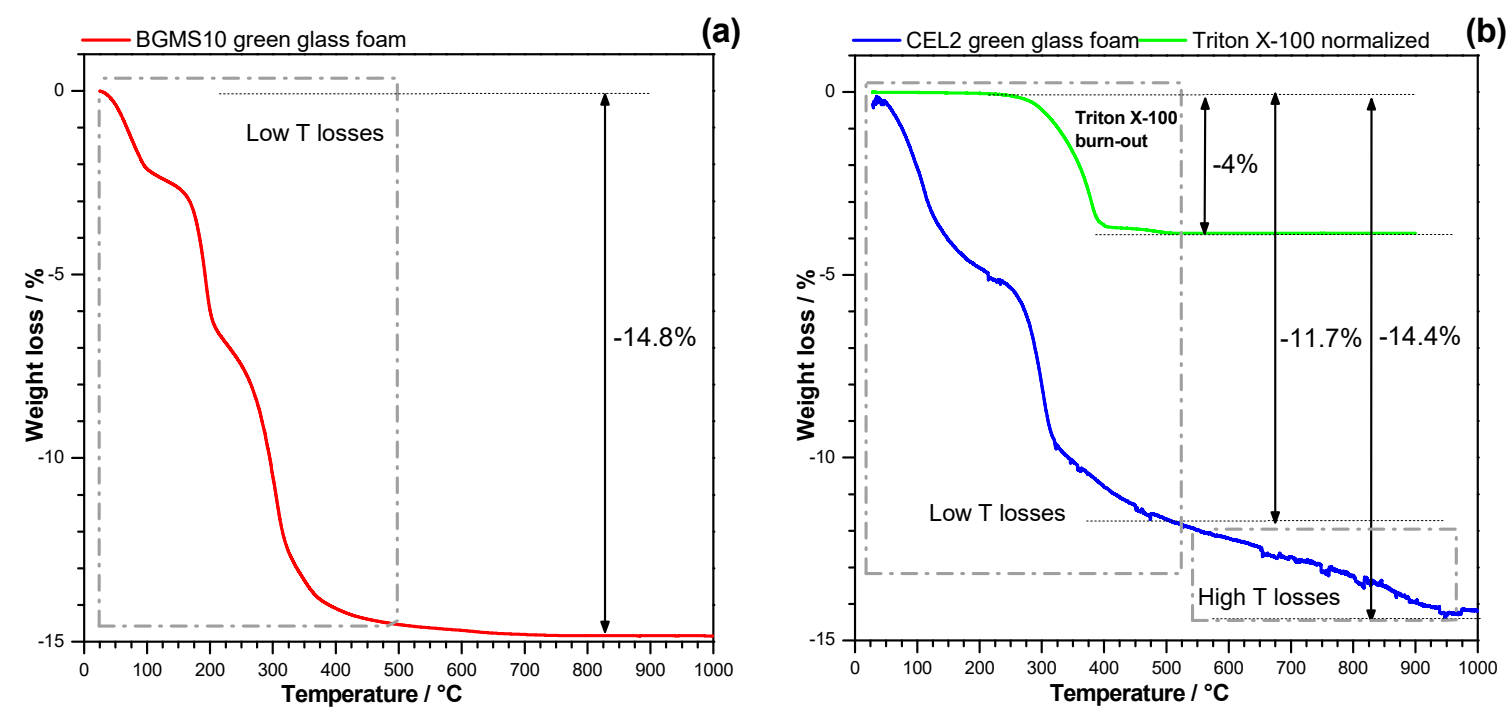

Figure 7. Comparison between BGMS10 glass activated with TMAH (a) and CEL2 glass activated with $\mathrm{NaOH}$ (b, adapted from Elsayed et al. [30]).

Previous experiments on glass-ceramic foams, from the activation of CEL2 bioactive glass [32], had revealed a substantial stimulation of crystallization, with the distinctive exothermic peak appearing broader and at much lowered temperature, interpreted as the effect of an alkali-enriched transient liquid layer from the decomposition of the binding gel on the surface of softened glass upon firing. The volumetric changes and ionic displacements in softened glass, associated with crystallization, could be somewhat catalyzed by a low viscosity extra phase (alkali rich glasses feature lower activation energy for crystal growth [46]), progressively dissolving in the same base glass. The differential scanning calorimetry plot shown in Figure 3 testifies that the crystallization tendency of BGMS10 was not significantly altered by the activation: the exothermic peak had a slight downshift but no broadening. A large exothermic effect was detected between 200 and $400{ }^{\circ} \mathrm{C}$, consistent with the burn-out of organic moieties.

The firing of green foams confirmed the open-celled structure available in the green state (Figure 5). As shown by Figure 8 (left), wide openings between adjacent cells (above $100 \mu \mathrm{m}$ ) were kept, while the 
cell walls had intensive densification, by viscous flow of BGMS10, to become nearly transparent. Such transparency was also a confirmation of the complete burn-out of organic additives, much before sintering could take place. Higher magnification details (shown in Figure 8, right) confirmed the formation of thin (but hollow) membranes. The presence of these membranes and the absence of any crack motivate the far higher strength-to-density ratio of foamed samples, compared to diamond cell scaffolds.
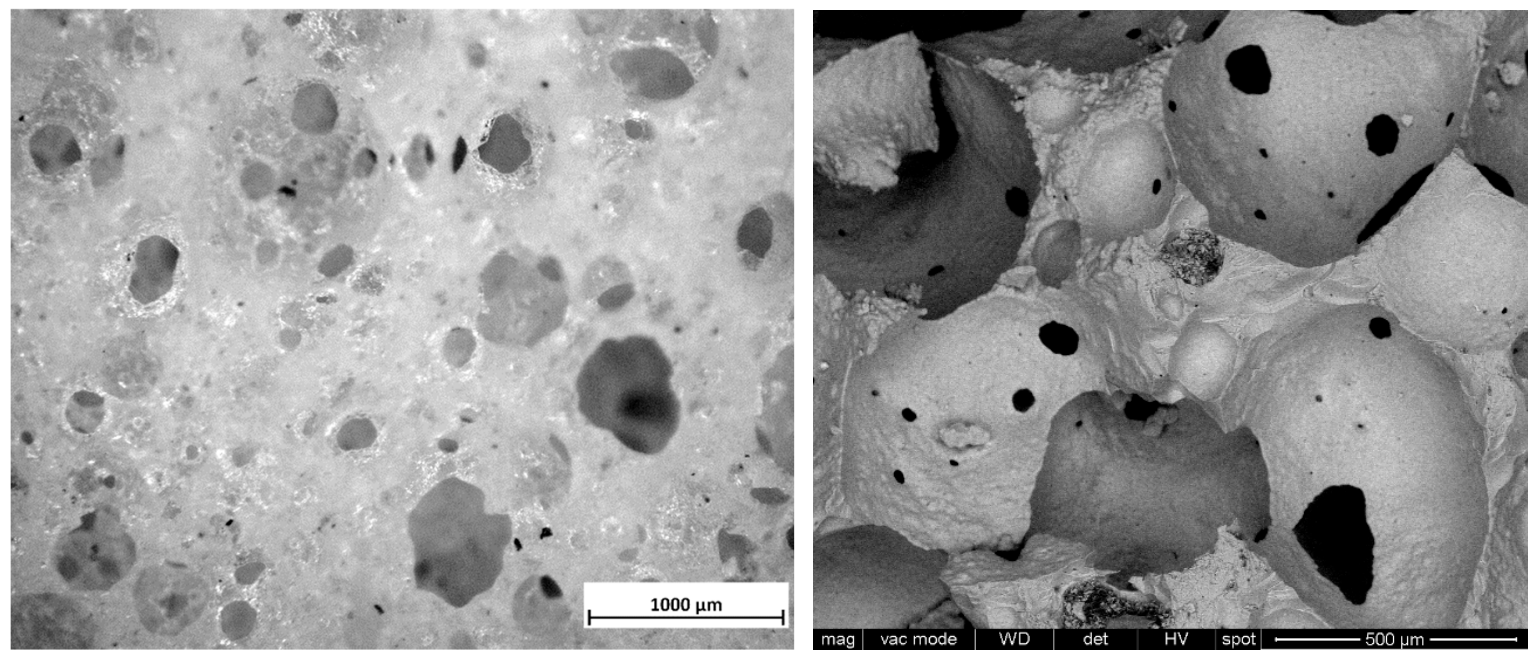

Figure 8. Fired foam: cellular structure (left, optical stereomicroscopy image); high magnification detail (right, SEM image).

The substantial lacking of any interference of the adopted shaping technologies on the evolution of BGMS10 bioactive glass suggests no change in the biological response compared to previous findings [14,15]. Anyway, cell tests will be considered, in the near future, for further validation. New investigations will include also the effect of secondary phases, which may benefit, in their stability, from the low sintering temperature. In particular, further studies will concern the use of BGMS10 mixed with hydroxylapatite powders, already tested for the manufacturing of dense discs [15].

\section{Conclusions}

The present study confirmed that BGMS10 bioactive glass, due to its characteristic processing window, could be applied for the manufacturing of highly porous open-celled components without viscous collapse. The viscous flow of BGMS10, although controlled, was effective in providing some healing of cracks developed upon firing of scaffolds with non-stochastic porosity due to the debinding of a commercial photocurable binder. The adopted digital light processing technique allowed for the easy obtainment of samples with different designs (to be further explored in the future). As an alternative to the printed scaffolds, open-celled foams (i.e., structures with stochastic porosity) could be obtained by a facile gel casting method, based on the activation of an aqueous suspension of glass powders, with a strong organic base. The gelation, unlike in previous experiments concerning the activation by means of inorganic bases (alkali hydroxides), had no impact on both chemistry and sintering of BGMS10.

Author Contributions: For this paper, E.B. and V.C. formulated research ideas, supervised the experiment on porous BGMS10 glass materials, and planned the structure of the article. H.E. and A.R.R. performed the general experimentation of the current work except for the glass preparation, which was done by D.B., H.E. and E.B. have written and edited the article.

Funding: This research received no external funding.

Acknowledgments: The authors thank Anna Silvia Pianalto for the experimental assistance.

Conflicts of Interest: The authors declare no conflict of interest. 


\section{References}

1. Rezwan, K.; Chen, Q.; Blaker, J.; Boccaccini, A.R.; Blaker, J. Biodegradable and bioactive porous polymer/inorganic composite scaffolds for bone tissue engineering. Biomaterials 2006, 27, 3413-3431. [CrossRef] [PubMed]

2. Boccaccini, A.R.; Erol, M.; Stark, W.J.; Mohn, D.; Hong, Z.; Mano, J.F. Polymer/bioactive glass nanocomposites for biomedical applications: A review. Compos. Sci. Technol. 2010, 70, 1764-1776. [CrossRef]

3. Rahaman, M.N.; Day, D.E.; Bal, B.S.; Fu, Q.; Jung, S.B.; Bonewald, L.F.; Tomsia, A.P. Bioactive glass in tissue engineering. Acta Biomater. 2011, 7, 2355-2373. [CrossRef]

4. Ray, A.; Tiwari, A. Compaction and sintering behaviour of glass-alumina composites. Mater. Chem. Phys. 2001, 67, 220-225. [CrossRef]

5. Rawson, H. Properties and Applications of Glass; Elsevier: Amsterdam, The Netherlands, 1980.

6. Bernardo, E.; Scarinci, G.; Edme, E.; Michon, U.; Planty, N. Fast-Sintered Gehlenite Glass-Ceramics from Plasma-Vitrified Municipal Solid Waste Incinerator Fly Ashes. J. Am. Ceram. Soc. 2009, 92, 528-530. [CrossRef]

7. Boccaccini, A. On the viscosity of glass composites containing rigid inclusions. Mater. Lett. 1998, 34, $285-289$. [CrossRef]

8. Li, P.; Yang, Q.; Zhang, F.; Kokubo, T. The effect of residual glassy phase in a bioactive glass-ceramic on the formation of its surface apatite layer in vitro. J. Mater. Sci. Mater. Med. 1992, 3, 452-456. [CrossRef]

9. Montazerian, M.; Zanotto, E.D. History and trends of bioactive glass-ceramics. J. Biomed. Mater. Res. Part A 2016, 104, 1231-1249. [CrossRef]

10. Crovace, M.C.; Souza, M.T.; Chinaglia, C.R.; Peitl, O.; Zanotto, E.D. Biosilicate®—A multipurpose, highly bioactive glass-ceramic. In vitro, in vivo and clinical trials. J. Non-Cryst. Solids. 2016, 432, 90-110. [CrossRef]

11. Fu, Q.; Rahaman, M.N.; Bal, B.S.; Brown, R.F.; Day, D.E. Mechanical and in vitro performance of 13-93 bioactive glass scaffolds prepared by a polymer foam replication technique. Acta Biomater. 2008, 4, 1854-1864. [CrossRef] [PubMed]

12. Bellucci, D.; Cannillo, V.; Sola, A. A New Highly Bioactive Composite for Scaffold Applications: A Feasibility Study. Materials 2011, 4, 339-354. [CrossRef] [PubMed]

13. Souza, M.T.; Renno, A.M.; Peitl, O.; Zanotto, E. New highly bioactive crystallization-resistant glass for tissue engineering applications. Transl. Mater. Res. 2017, 4, 014002. [CrossRef]

14. Bellucci, D.; Cannillo, V. A novel bioactive glass containing strontium and magnesium with ultra-high crystallization temperature. Mater. Lett. 2018, 213, 67-70. [CrossRef]

15. Bellucci, D.; Salvatori, R.; Anesi, A.; Chiarini, L.; Cannillo, V. SBF assays, direct and indirect cell culture tests to evaluate the biological performance of bioglasses and bioglass-based composites: Three paradigmatic cases. Mater. Sci. Eng. C 2019, 96, 757-764. [CrossRef] [PubMed]

16. Hoppe, A.; Güldal, N.S.; Boccaccini, A.R. A review of the biological response to ionic dissolution products from bioactive glasses and glass-ceramics. Biomaterials 2011, 32, 2757-2774. [CrossRef] [PubMed]

17. Bellucci, D.; Cannillo, V.; Anesi, A.; Salvatori, R.; Chiarini, L.; Manfredini, T.; Zaffe, D. Bone Regeneration by Novel Bioactive Glasses Containing Strontium and/or Magnesium: A Preliminary In-Vivo Study. Materials 2018, 11, 2223. [CrossRef] [PubMed]

18. Jones, J.R.; Hench, L.L. Factors affecting the structure and properties of bioactive foam scaffolds for tissue engineering. J. Biomed. Mater. Res. Part B: App. Biomater. 2004, 68, 36-44. [CrossRef] [PubMed]

19. Zocca, A.; Colombo, P.; Gomes, C.M.; Günster, J. Additive Manufacturing of Ceramics: Issues, Potentialities, and Opportunities. J. Am. Ceram. Soc. 2015, 98, 1983-2001. [CrossRef]

20. Travitzky, N.; Bonet, A.; Dermeik, B.; Fey, T.; Filbert-Demut, I.; Schlier, L.; Schlordt, T.; Greil, P. Additive Manufacturing of Ceramic-Based Materials. Adv. Eng. Mater. 2014, 16, 729-754.

21. Jang, J.H.; Wang, S.; Pilgrim, S.M.; Schulze, W.A. Preparation and characterization of barium titanate suspensions for stereolithography. J. Am. Ceram. Soc. 2000, 83, 1804-1806. [CrossRef]

22. Halloran, J.W.; Tomeckova, V.; Gentry, S.; Das, S.; Cilino, P.; Yuan, D.; Guo, R.; Rudraraju, A.; Shao, P.; Wu, T.; et al. Photopolymerization of powder suspensions for shaping ceramics. J. Eur. Ceram. Soc. 2011, 31, 2613-2619. [CrossRef]

23. Elsayed, H.; Zocca, A.; Schmidt, J.; Günster, J.; Colombo, P.; Bernardo, E. Bioactive glass-ceramic scaffolds by additive manufacturing and sinter-crystallization of fine glass powders. J. Mater. Res. 2018, 33, 1960-1971. [CrossRef] 
24. Elsayed, H.; Schmidt, J.; Bernardo, E.; Colombo, P. Comparative Analysis of Wollastonite-Diopside Glass-Ceramic Structures Fabricated via Stereo-Lithography. Adv. Eng. Mater. 2019, 21, 1801160. [CrossRef]

25. Tesavibul, P.; Felzmann, R.; Gruber, S.; Liska, R.; Thompson, I.; Boccaccini, A.R.; Stampfl, J. Processing of $45 S 5$ Bioglass ${ }^{\circledR}$ by lithography-based additive manufacturing. Mater. Lett. 2012, 74, 81-84. [CrossRef]

26. Gmeiner, R.; Deisinger, U.; Schönherr, J.; Lechner, B.; Detsch, R.; Boccaccini, A.R.; Stampfl, J. Additive Manufacturing of Bioactive Glasses and Silicate Bioceramics. J. Ceram. Sci. Tech. 2015, 06, 75-86.

27. Jones, J.; Hench, L.L. Effect of surfactant concentration and composition on the structure and properties of sol-gel-derived bioactive glass foam scaffolds for tissue engineering. J. Mater. Sci. 2003, 38, 3783-3790. [CrossRef]

28. Poologasundarampillai, G.; Lee, P.D.; Lam, C.; Kourkouta, A.; Jones, J.R. Compressive Strength of Bioactive Sol-Gel Glass Foam Scaffolds. Int. J. Appl. Glas. Sci. 2016, 7, 229-237. [CrossRef]

29. Wu, Z.Y.; Hill, R.G.; Yue, S.; Nightingale, D.; Lee, P.D.; Jones, J.R. Melt-derived bioactive glass scaffolds produced by a gel-cast foaming technique. Acta Biomater. 2011, 7, 1807-1816. [CrossRef]

30. Novajra, G.; Perdika, P.; Pisano, R.; Miola, M.; Bari, A.; Jones, J.; Detsch, R.; Boccaccini, A.R.; Vitale-Brovarone, C. Structure optimisation and biological evaluation of bone scaffolds prepared by co-sintering of silicate and phosphate glasses. Adv. Appl. Ceram. 2015, 114, S48-S55. [CrossRef]

31. Rincón, A.; Giacomello, G.; Pasetto, M.; Bernardo, E. Novel 'inorganic gel casting' process for the manufacturing of glass foams. J. Eur. Ceram. Soc. 2017, 37, 2227-2234. [CrossRef]

32. Elsayed, H.; Romero, A.R.; Molino, G.; Brovarone, C.V.; Bernardo, E. Bioactive Glass-Ceramic Foam Scaffolds from 'Inorganic Gel Casting' and Sinter-Crystallization. Materials 2018, 11, 349. [CrossRef] [PubMed]

33. Romero, A.R.; Tamburini, S.; Taveri, G.; Toušek, J.; Dlouhy, I.; Bernardo, E. Extension of the 'Inorganic Gel Casting' Process to the Manufacturing of Boro-Alumino-Silicate Glass Foams. Materials 2018, 11, 2545. [CrossRef] [PubMed]

34. Elsayed, H.; Romero, A.R.; Ferroni, L.; Gardin, C.; Zavan, B.; Bernardo, E. Bioactive Glass-Ceramic Scaffolds from Novel 'Inorganic Gel Casting' and Sinter-Crystallization. Materials 2017, 10, 171. [CrossRef] [PubMed]

35. Gibson, L.J.; Ashby, M.F. Cellular Solids, Structure and Properties, 2nd ed.; Cambridge University Press: Cambridge, UK, 1999.

36. Mecholsky, J.J.; Rice, R.W.; Freiman, S.W. Prediction of Fracture Energy and Flaw Size in Glasses from Measurements of Mirror Size. J. Am. Ceram. Soc. 1974, 57, 440-443. [CrossRef]

37. Tetramethylammonium Hydroxide. Available online: http://www.hanhonggroup.com/ir/ir_en/RF09010003. html (accessed on 20 September 2019).

38. Lv, X.; Liu, C.; Song, S.; Qiao, Y.; Hu, Y.; Li, P.; Lia, Z.; Sun, S. Construction of a quaternary ammonium salt platform with different alkyl groups for antibacterial and biosensor applications. RSC Adv. 2018, 8, 2941. [CrossRef]

39. Wang, Y.-L.; Liu, C.; Chang, S.-T.; Tsai, M.-S.; Feng, M.-S.; Tseng, W.-T. Chemical-mechanical polishing of low-dielectric-constant spin-on-glasses: Film chemistries, slurry formulation and polish selectivity. Thin Solid Films 1997, 308, 550-554. [CrossRef]

40. Prasetyoko, D.; Ramli, Z.; Endud, S.; Hamdan, H.; Sulikowski, B. Conversion of rice husk ash to zeolite beta. Waste Manag. 2006, 26, 1173-1179. [CrossRef]

41. Calabro, D.C.; Valyocsik, E.W.; Ryan, F.X. In situ ATR/FTIR study of mesoporous silicate syntheses. Microporous Mater. 1996, 7, 243-259. [CrossRef]

42. Del Bosque, I.S.; Martinez-Ramirez, S.; Blanco-Varela, M. FTIR study of the effect of temperature and nanosilica on the nano structure of C-S-H gel formed by hydrating tricalcium silicate. Constr. Build. Mater. 2014, 52, 314-323. [CrossRef]

43. Kooli, F. Recrystallization of a new layered silicate from Na-kanemite-tetramethylammonium hydroxide-water-1,4-dioxane mixture. J. Mater. Chem. 2002, 12, 1374-1380. [CrossRef]

44. Sakai, N.; Nakano, T.; Yanaba, K.; Imazeki, S. Studies of the characteristic and reaction mechanism of silica xerogel by sol-gel method catalyzed by alkylbiguanide as a strong organic base. J. Sol-Gel Sci. Technol. 2018, 88, 379-385. [CrossRef] 
45. Zhang, Q.; Ye, G. Dehydration kinetics of Portland cement paste at high temperature. J. Therm. Anal. Calorim. 2012, 110, 153-158. [CrossRef]

46. Watanabe, T.; Hashimoto, H.; Hayashi, M.; Nagata, K. Effect of Alkali Oxides on Crystallization in CaO-SiO2-CaF2 Glasses. ISIJ Int. 2008, 48, 925-933. [CrossRef] 